$$
\text { Bujáki fános - Pataki János Istuán }
$$

\title{
A mikro- és kisvállalkozások innovációs gyakorlatának különbségei
}

\section{Differences in the Innovation Practices of Micro- and Small Enterprises}

\section{Összefoglalás}

Munkánk célja a magyarországi mikro- és kisvállalkozások nemzetgazdasági jelentőségének bemutatása. Dolgozatunk eredményeit a jelen kori kapcsolódó jogszabályi (kiemelésre kerültek a COVID-19 okozta egészségügyi veszélyhelyzet okozta gazdasági válsághelyzetre vonatkozó, a kormányzat által bevezetésre került programok) és szakirodalmi háttér áttekintése mellett egy 2019-ben készült kérdőíves megkérdezésre alapoztuk. Primer kutatásunk vizsgálatai a két méretkategória közötti különbségekre koncentrálnak a döntéshozatali gyakorlat, a forrásfelvételi lehetőségek, a beruházási és innovációs hajlandóság, valamint a tervezési időhorizont területén. A 169 mikrovállalkozás és 86 kisvállalkozás vezetőjétől származó adatokat statisztikai módszerekkel elemeztük. A kapott eredmények a legtöbb esetben arról tanúskodtak, hogy a nagyobb vállalati létszámmal múködő vállalkozások jelentősen kedvezőbb helyzetben működtek a piacon: üzleti tervezésük hosszabb távú, innovációs és beruházási hajlandóságuk magasabb, forrásfelvételi lehetőségeik jobbak a kisebb létszámú vállalkozásokéinál.

Journal of Economic Literature (JEL) kódok: G28, G30, G41, H12, O1 1, O12, Y10 Kulcsszavak: mikrovállalkozás, kisvállalkozás, innováció, beruházás, tervezés, forrás, kormányzati programok

BuJÁKiJÁNos, doktorandusz hallgató, MATE GRDI, janos.bujaki@protonmail. com), Dr. Pataki János István PhD LL. M. ügyvéd, Edutus Egyetem c. föiskolai docens (patakiugyvediiroda@gmail.com). 
Bujáki fános - Pataki fános István: A mikro-és kisvállalkozások innovációs gyakorlatának...

\section{Summary}

The main objective of our paper is to present the significance of micro- and small enterprises in the Hungarian national economy. The results of our work are based on an overview of related current legislation (highlighting programmes introduced by the government in relation to the economic crisis created by the medical emergency caused by COVID-19) and literature along with analyses of questionnaire data collected in 2019. Our primary research studies focused on analysing the differences between the two aforementioned size categories in terms of their decision-making practice, opportunities of obtaining credit, willingness to invest and innovate as well as planning horizon. In order to analyse the answers received from the general managers of 169 micro-enterprises and 86 small enterprises, we applied statistic methods. Results received mostly indicated that small enterprises - compared to the micro ones - possessed a significantly more favourable situation on the market: they were able to make a business plan for a longer period of time, had a greater willingness to invest and innovate as well as better opportunities to obtain credit.

Journal of Economic Literature (JEL) codes: G28, G30, G41, H12, O1 1, O12, Y10 Keywords: micro-enterprise, small enterprise, innovation, investment, planning, financial sources, government programmes

\section{BEVEZETÉS}

Az innováció témakörével foglalkozó akadémiai szakirodalmak többsége a nagyvállalatokra koncentrál, míg a mikro- és kisvállalkozásokra irányuló kutatási eredmények alkalmazhatósága ezen a területen korlátozott (Andrew-Sirkin, 2003; Drucker, 2002). Sőt, Baltas (2004) és Battisti (2010) egyaránt azon a véleményen van, hogy a kimondottan a mikro- és kisvállalkozások innovációjáról szóló tanulmányokból hiány mutatkozik. Ezzel a megállapítással teljesen egyetértve kell megjegyeznünk, hogy a releváns területen elérhető magyar nyelvű szakirodalom gyakorlatilag szintén nem foglalkozik kiemelten, illetve önállóan a mikro- és kisvállalkozások körével - a hazai publikációk jellemzően „csak” a kkv-szektorral foglalkoznak, és nem szúkítik a vizsgálati területet a specifikusabb, konkrétabb eredmények elérése céljából egy-egy méretkategóriára. Erre a problémára Faherty és Stephens (2016) is felhívja a figyelmet kiemelve azt, hogy a mikrovállalkozások alacsony innovációs hajlandóságában többek között a rövid tervezési horizont, a megfelelő képzettségủ alkalmazottak hiánya, a megfelelő tanácsadói környezet hiánya és az elégtelen IT-infrastruktúra is szerepet játszik. Faherty és Stephens (2016) azonban hangsúlyozza azt is, hogy a mikrovállalkozásokra jellemző gyors döntéshozatal, a rugalmasság, a személyes és közvetlen kommunikáció, valamint az egyszerủbb folyamatok támogathatják az innovációt. Az alacsony létszámú szervezetekben azonban valamennyi területen döntő jelentőségű a vezető stílusa, a szubjektum (Vonnák, 2019:26-27). De Sousa (2006) szerint a szervezeti tanulás kultúrájának megléte elengedhetetlen a fenntartható innováció szempontjából. Sok vállalkozó autokratikus vezetési stílusa azonban nem tá- 
mogatja, nem bátorítja az innovációt, a rugalmasságot és a kockázatvállalást. Az ilyen vezetési stílus pedig letörheti a dolgozók innovatív és kreatív hajlandóságát.

\section{A Mikro- És KisvállalkozÁSOK}

Magyarországon a kis- és középvállalkozások fogalmának meghatározását önálló jogszabály, a 2004. évi XXXIV. törvény - a kis- és középvállalkozásokról, fejlődésük támogatásáról (a továbbiakban: $\mathrm{Kkv}$. tv.) rögzíti ${ }^{1}$, amely iránymutatást is biztosít ezen vállalkozások részére a fejlődés, a fejlesztés főbb paraméterrendszerére nézve. A törvényi fogalommeghatározás szerint KKV alatt, mikro-, kis- és középvállalkozást, illetve kis- és középvállalkozást kell érte$n^{2}$. A Kkv. tv. meghatározza azt is, hogy mely esetekben nem beszélhetünk törvény szerinti KKV-ról ${ }^{3}$. A Kkv. törvény ugyanakkor a korlátozások szűkítése mellett tovább tágítja a KKV fogalom alá tartozó érintetti körtt ${ }^{4}$.

1. táblázat: A mikro-, kis- és középvállalkozások besorolása

\begin{tabular}{c|c|c|c|c}
\hline Megnevezés & $\begin{array}{c}\text { Összes } \\
\text { foglalkoztatotti } \\
\text { létszáma kevesebb } \\
\text { mint (fó) }\end{array}$ & $\begin{array}{c}\text { Éves nettó árbevétel* } \\
\text { legfeljebb (millió euró) }\end{array}$ & $\begin{array}{c}\text { Mérlegföösszeg* } \\
\text { legfeljebb (millió } \\
\text { euró) }\end{array}$ \\
\hline Középvállalkozás & 250 & 50 & vagy & 43 \\
\hline Kisvállalkozás & 50 & 10 & vagy & 10 \\
\hline Mikrovállalkozás & 10 & 2 & vagy & 2 \\
\hline
\end{tabular}

Forrás: Kormányhivatal, https://wrere.kormanyhivatal.hu/download/1/ab/f5000/T\%C3\%817\%C3\%89KOZTAT\%C3\%93\%20-\%20KKV-k\%20besorol\%C3\%A1sa.pdf (2021. 06. 30.)

A 250 fő alatti létszámmal működő vállalkozások ${ }^{5}$ a legtöbb gazdaságban a gazdasági társaságok túlnyomó részét, gyakran több mint 90\%-át teszik ki, és az innováció egyik fontos forrásának számítanak (OECD, 2010). A fenntartható és folyamatos növekedés ezen vállalatok vezetői és tulajdonosai számára az egyik legnagyobb, állandó kihívást jelentik (Mazzarol et al.,2014:54-55). Noha a legtöbb stratégiai menedzsment elmélet és modell a nagyvállalati működés tanulmányozása mentén került kifejlesztésre, léteznek kutatási irányzatok, amelyek kimondottan a kisvállalatok stratégiájával és tervezésével foglalkoznak (Woods és Joyce, $2003)^{6}$. A kisvállalatok növekedési képességét azonban a célpiaci szegmentum meghatározása és a formális stratégiai tervezés mellett a vállalaton kívüli partnerek, azaz a szállítók, vevők, hitelintézetek is befolyásolják (Woods és Joyce, 2003)굴 vagyis a külső makrogazdasági, illetve ezen esetben jórészt a külső mikrogazdasági körülmények és hatások.

A Központi Statisztikai Hivatal adatai alapján (2019) „a 2018. évi elözetes adatok alapján a Magyarországon müködö vállalkozások 99,1\%-a volt kis- és középvállalkozás. Miközben a kis-és középvállalkozások a vállalkozási szférában foglalkoztatottak közel kétharmadának biztositottak munkalehetöséget, a hozzáadott érték 46, a nettó árbevétel 42, a nemzetgazdasági beruházások $30 \%$-ával járultak hozzá a müködö vállalkozások összteljesitményéhez 2018-ban.”.Az adatokból egyértelmű módon kitűnik, hogy a kisvállalkozások súlya és szerepe a társadalom, a társadalmi alrendszerek és a gazdaság 
Bujáki János - Pataki fános István: A mikro-és kisvállalkozások innovációs gyakorlatának...

szempontjából is kiemelkedő jelentőséggel rendelkezik, így ennek okán mindenképpen szűkített körben, különféle mátrix rendszereket létrehozva részletesebb kutatást és vizsgálatokat is érdemes végezni a témában, de ki kell emelni, hogy nagyon csekély mennyiségű reprezentatív és valós idejű adat áll csak rendelkezésre. Ezért mutatkozott szükségesnek az önálló kérdőíves adatfelmérés elvégzése.

2. táblázat: A vállalkozások teljesitménymutatói kis-és középvállalkozási kategória szerint (2019)

\begin{tabular}{|c|c|c|c|c|c|c|c|}
\hline $\begin{array}{l}\text { KKV kate- } \\
\text { gória }\end{array}$ & $\begin{array}{c}0 \text { fós mik- } \\
\text { rováll. }\end{array}$ & $\begin{array}{c}1 \text { fós mik- } \\
\text { rováll. }\end{array}$ & $\begin{array}{l}\text { 2-9 fós } \\
\text { mikro- } \\
\text { váll. }\end{array}$ & Kisváll. & $\begin{array}{l}\text { Közép- } \\
\text { váll. }\end{array}$ & Nem KKV & Összesen \\
\hline $\begin{array}{l}\text { Vállalk. szá- } \\
\text { ma, darab }\end{array}$ & 33.130 & 552.092 & 200.851 & 35.092 & 5.351 & 9.504 & 836.020 \\
\hline $\begin{array}{l}\text { Foglalk. } \\
\text { létszám, fö }\end{array}$ & - & 552.092 & 668.090 & 558.906 & 362.200 & 1.146 .833 & 3.288 .121 \\
\hline $\begin{array}{c}\text { Egy fog- } \\
\text { lalk.-ra jutó } \\
\text { árbevétel, } \\
\text { eFt/fó }\end{array}$ & - & 8.738 & 15.441 & 28.777 & 43.667 & 62.126 & 35.992 \\
\hline $\begin{array}{c}\text { Foglalk. } \\
\text { létszám } \\
\text { megoszlása, } \\
\text { \% }\end{array}$ & - & 16,8 & 20,3 & 17 & 11 & 34,9 & 100 \\
\hline $\begin{array}{l}\text { Értékesítés } \\
\text { nettó árbe- } \\
\text { vétele, mFt }\end{array}$ & 56.528 & 4.823 .965 & 10.316 .283 & 16.083 .793 & 15.816 .138 & 71.248 .317 & 118.345 .025 \\
\hline $\begin{array}{l}\text { Értékesítés } \\
\text { nettó árbev. } \\
\text { megoszálá- } \\
\text { sa \% }\end{array}$ & 0 & 4,1 & 8,7 & 13,6 & 13,4 & 60,2 & 100 \\
\hline $\begin{array}{l}\text { Hozzáadott } \\
\text { érték (ténye- } \\
\text { ző- költsé- } \\
\text { gen), mFt }\end{array}$ & 21.714 & 1.661 .395 & 3.299 .792 & 4.204 .687 & 3.385 .603 & 15.615 .082 & 28.188 .272 \\
\hline $\begin{array}{l}\text { Hozzáadott } \\
\text { érték (ténye- } \\
\text { ző- költsé- } \\
\text { gen) meg- } \\
\text { oszlása, \% }\end{array}$ & 0,1 & 5,9 & 11,7 & 14,9 & 12 & 55,4 & 100 \\
\hline $\begin{array}{c}\text { Export- } \\
\text { értékesítés } \\
\text { árbevétele, } \\
\mathrm{mFt}\end{array}$ & 522 & 189.235 & 361.985 & 1.533 .559 & 3.264 .289 & 32.814 .387 & 38.163 .978 \\
\hline
\end{tabular}

Forrás: KSH, https://wrere.ksh.hu/docs/hun/xstadat/xstadat_eves/i_qta005.html (2021. 06. 30.) 


\section{Alkalmazott Módszertan}

A vizsgálatok a méretkategóriák közötti különbségek és hasonlóságok megállapítását célozták. A beruházási és innovációs hajlandóság különbségeit khi-négyzet próbával vizsgáltuk. A releváns esetekben kiemeltük az adjusztált standardizált reziduumok értékét. A tervezési időhorizont és a forráshoz jutási lehetőség összefüggéseit szintén khi-négyzet próbával elemeztük. A kérdőíves felmérés egyes területeihez tartozó változók összevont mérése céljából főkomponens-analízist végeztünk. A főkomponens-koordinátákat Mann-Whitney nem paraméteres próbával vizsgáltuk a méretkategóriák közötti átfogó különbségek megállapítása céljából. A felmérés során megvalósítás alatt álló beruházások és a forráshoz jutási lehetőségek összefüggéseit khi-négyzet próbával vizsgáltuk.

A vizsgálatok a méretkategóriák közötti különbségek és hasonlóságok megállapítását célozták. A mikro- és kisvállalkozások beruházási és innovációs hajlandóságában esetlegesen fennálló különbségeket a khi-négyzet próbával vizsgáltuk. A próba szignifikáns eredménye esetében az adjusztált standardizált reziduálisok alapján határoztuk meg azon kategóriákat, amelyek esetén jelentősnek tekinthető az eltérés: a standardizált reziduális kettőt elérő abszolút értéke mellett jelentősnek tekintettük az eltérést. A tervezési időhorizont és a forráshoz jutási lehetőség összefüggéseit szintén khi-négyzet próbával elemeztük. A kérdőíves felmérés egyes területeihez tartozó változók összevont mérése céljából főkomponens-analízist végeztünk. A méretkategóriák közötti különbségeket a Mann-Whitney nemparaméteres próbával vizsgáltuk a főkomponens-koordinátákban azonosított szakmai területek esetében. A főkomponens-elemzés alkalmazhatóságát a Kaiser-Meyer-Olkin (KMO) mutató és a Bartlett-próba alapján ellenőriztük. A statisztikai vizsgálatokban alkalmazott hibaszint: 0,05.

\section{DÖNTÉShOZATAl a MIKRO- ÉS KISVÁllaLKOZÁSOK ESETÉBEN}

A kisvállalatok vezetői és tulajdonosai stratégiai döntéseiket következetesen intuitív alapon, semmint tudományos elvek és modellek alapján hozzák meg (Ennis, 1998). Ennis megállapítása egybeesik és azonos eredményt tükröz az általunk a 2019. évben végzett kutatással, melyben a 255 válaszadó mikro- és kisvállalkozás vezetőjének 69 \%-a úgy válaszolt, hogy cége nem rendelkezik írásos üzleti tervvel. Üzleti partnereikkel való megbeszéléseik alapján kétharmad részük, megérzéseik alapján viszont 84,7 \%-uk dönt a vezetett cég jövőjét illetően. Belső riportok és jelentések alapján alig egytized részük, ERP-rendszerből származó információk segítségével elenyésző hányaduk dönt, de a számvitelből, könyveléstől kapott adatokat is csak alig egyharmaduk használja fel a döntéshozatal során. 
Bujáki János - Pataki fános István: A mikro-és kisvállalkozások innovációs gyakorlatának...

1. ábra: Ön mi alapján hozza meg üzleti döntéseit vállalkozásában?

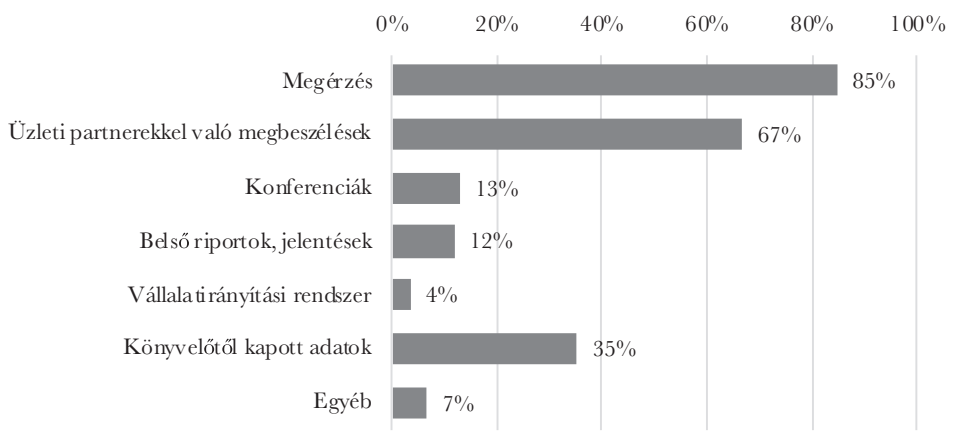

Forrás: saját adatgyujités és számítás

Az informális és intuitív menedzsment stílust követő vállalatok alacsonyabb növekedési rátát tudnak elérni a jól átgondolt, aprólékosan tervezett menedzsmentet követő versenytársaikénál (Lyles et al., 1993:39-42). Ez hosszú távon a versenyben való lemaradáshoz, majd a piacról való kiszoruláshoz vezethet. A stratégiai menedzsment eszközök használata azonban a kisvállalkozások növekedését is bizonyítottan támogatja (Woods - Joyce, 2003:181-183). Ezért egy vállalat növekedéséhez véleményünk szerint olyan szemléletű vezetőre van szükség, aki a profitmaximalizálás alapelve mellett folyamatosan figyelemmel van a növekedésre és az ehhez szükséges innovációra. Miller (1983) szerint a vállalkozói szellemű vezetés kezdeményezőként lép fel a termék és marketing innováció területén, bizonyos mértékủ kockázatot vállal, és elsőként hajt végre proaktív innovációkat, amelyek alkalmassá teszik a versenytársainál jobb teljesítmény elérésére. Miller 1983-ban publikált tanulmánya óta azonban a vállalatok, különösen a kisvállalatok mikro- és makrokörnyezete jelentősen komplexebbé vált. Ma egy kisvállalkozás vezetőjének sokkal jobban meg kell osztania figyelmét a jogszabályi, adózási és egyéb szabályozási megfelelések miatt, így a cég menedzselésére és az üzleti tervezésre kevesebb ideje jut(Faherty - Stephens, 2016:46). Tudatos stratégiai tervezés nélkül azonban véleményünk szerint a vállalkozások nem képesek versenyelőnyöket biztosító fejlesztésekre, így előbb-utóbb kiszorulnak a piacról. Ez azért probléma, mert bár ezek a vállalkozások ugyan „kicsik” - azaz jellemzően lokálisan, alacsony számú személyzettel múködők -, mégis sokan vannak, a magánszektoron belüli hozzáadott értékük és teljes alkalmazotti létszámuk viszont a nemzetgazdaságon belül már jelentős (Csath et al., 2018).

A jogalkotó a Kkv. tv. megalkotásával különös hangsúlyt kívánt helyezni a kisvállalkozások fejlesztésére, azok fejlődési lehetőségeinek biztosítására, a forrásbevonás eszközrendszerének kialakítására is akként, hogy meghatározta a jelentkező állami feladatokat ${ }^{8}$, valamint létrehozta a Vállalkozásfejlesztési Tanácsot ${ }^{9}$. A jogszabályi indokolás ekként fogalmaz: „A Vállalkozásfejlesztési Tanács (a továbbiakban: VT) összetételénél fogva alkalmas arra, hogy a KKV-fejlesztésben érintett szervezetek közötti érdekeket összehangolja, továbbá arra, hogy a KKV-k, illetve szervezeteik részt vegyenek az oóket érintö döntések elókészitésében." 
A továbbiakban egyrészt annak vizsgálatával foglalkozunk, hogy milyen különbségek és azonosságok igazolhatók az 50 főnél kisebb dolgozói létszámú vállalkozások működésében azok tervezési és innovációs gyakorlatának területén. Másrészt - nem lehet eltekinteni - a jelenkorukban az egészségügyi veszélyhelyzet egyik következményeképpen kialakult gazdasági válsághelyzet által generált gazdasági mikrokörnyezeti változásoktól, vizsgáljuk a kormányzat által megalkotásra került, bevezetett és életre hívott támogatások rendszerét (a terjedelmi korlátok okán természetesen nem teljes körűen, csak az egyes jogszabályi keretek mentén).

\section{BERUHÁZÁSI HAJLANDÓSÁG, INNOVÁGIÓ}

A beruházási hajlandóságot a kérdőív a múltra, a jelenre és a jövőre vonatkozóan is felmérte. Elsőként azt vizsgáljuk meg, hogy milyen különbségek és hasonlóságok igazolhatóak statisztikailag a két méretkategória között. A vizsgálatokat khi-négyzet próbával végeztük. Új terméket és CRM-rendszert a mikro- és kisvállalkozások a felmérést megelőző öt évben hasonló arányban vezettek be, így a különbség a két méretkategória között egyik területen sem jelentős. A szignifikáns különbség határát jelentő p-érték $(\mathrm{p}<=0,05)$ feletti az eredmény az új munkaszervezés esetében ( $\mathrm{p}=0,055)$, így jelentős különbség ebben a tekintetben sincs a mikroés kisvállalkozások között.

Új szolgáltatás bevezetése esetében viszont már jelentős különbségről beszélhetünk: a kisvállalkozások több mint másfélszeres arányban hajtottak végre ilyen típusú innovációt a mikrovállalkozásokhoz képest (adjusztált standardizált reziduum = 2,1). Míg a kisvállalkozások közel 30\%-a vezetett be új technológiát - vagy korszerűsítette a meglévőt -, addig a mikrovállalkozások körében ez az arány 15\% alatti, így a különbség ezen a területen is jelentős (adjusztált standardizált reziduum = 2,8). A különbség azonban a két méretkategória között a vállalatirányítási rendszer bevezetésében volt a legjelentősebb: a mikrovállalkozások körében az arány $1 \%$ alatti, a kisvállalkozásokat tekintve viszont minden 6 . vagy 7 . vezető nyilatkozott úgy, hogy a felmérést megelőző öt évben elkezdtek valamilyen ERP-rendszert használni (adjusztált standardizált reziduum $=4,8$ ).

Összességében elmondható az, hogy a különböző típusú innovációkat figyelembe véve minden esetben magasabb arányban voltak jelen az innovátorok a kisvállalkozások, mint a mikrovállalkozások körében. Ezzel együtt a mikrovállalkozások közel 60\%-a, míg a kisvállalkozások közül csak minden harmadik nyilatkozott úgy, hogy semmilyen innováció nem történt cégükben. Mára, amikor a digitalizáció korát éljük, fontos kiemelnünk, hogy mindkét méretkategóriában a digitalizációs célú beruházások bizonyultak mindezidáig, az elmúlt kb. öt éves adatok szerint a legritkábbnak. Ugyanakkor ki kell hangsúlyozni, és látni kell azt, hogy teljes bizonyossággal kijelenthető, hogy a jelen napjainkra az egészségügyi veszélyhelyzet és a kapcsolódó válsághelyzet által generált krízishelyzet, a társadalmi igényszint változása felértékelte az informatikai fejlesztések, az ez irányú innováció szerepét - bár erre nézve a kisvállalkozások körében jelenleg még nem áll rendelkezésre adat, illetve nem állnak rendelkezésre vizsgálati eredmények sem - biztos, hogy az ilyen irányú beruházások aránya jelentősen megnövekedett többek között a kialakult informatikai beruházási kényszernek ${ }^{10}$ köszönhetően (pl. ebben a körben az ún. home office térnyerése és általános jellegűvé válása 
Bujáki fános - Pataki János István: A mikro- és kisvállalkozások innovációs gyakorlatának...

stb.). A kormányzat a kialakításra került vállalkozáskezelési stratégia (Matolcsy, 2020a:205231) keretein belül, kifejezetten a kisvállalkozások részére, a technológiai támogatások elősegítése érdekében életre hívta a GINOP-8.3.5-18 mikro-, kis- és középvállalkozások technológiai korszerűsítése célú hitelprogramot ${ }^{11}$.

3. táblázat: A vállalkozások által az elmúlt öt évben megvalósitott innovációk

\begin{tabular}{|c|c|c|c|c|c|c|}
\hline \multirow{2}{*}{$\begin{array}{c}\text { Az elmúlt } 5 \\
\text { évben megvaló- } \\
\text { sított innováció } \\
\text { típusa }\end{array}$} & \multicolumn{2}{|c|}{$\begin{array}{l}\text { Mikrovállalkozások } \\
\qquad(\mathrm{n}=169)\end{array}$} & \multicolumn{2}{|c|}{$\begin{array}{c}\text { Kisvállalkozások } \\
(\mathbf{n}=\mathbf{8 6})\end{array}$} & \multicolumn{2}{|c|}{$\begin{array}{c}\text { khi-négyzet próba } \\
\text { eredménye }\end{array}$} \\
\hline & történt & $\begin{array}{l}\text { nem tör- } \\
\text { tént }\end{array}$ & történt & $\begin{array}{l}\text { nem tör- } \\
\text { tént }\end{array}$ & p-érték & $\begin{array}{l}\text { szignifi- } \\
\text { káns kü- } \\
\text { lönbség }\end{array}$ \\
\hline Új termék & $11,24 \%$ & $88,76 \%$ & $16,28 \%$ & $83,72 \%$ & 0,257 & nincs \\
\hline Új szolgáltatás & $19,53 \%$ & $80,47 \%$ & $31,40 \%$ & $68,60 \%$ & 0,035 & van \\
\hline $\begin{array}{l}\text { ERP-rendszer } \\
\text { bevezetése }\end{array}$ & $0,59 \%$ & $99,41 \%$ & $15,12 \%$ & $84,88 \%$ & $<0,001$ & van \\
\hline $\begin{array}{l}\text { CRM-rendszer } \\
\text { bevezetése }\end{array}$ & $4,73 \%$ & $95,27 \%$ & $6,98 \%$ & $93,02 \%$ & 0,457 & nincs \\
\hline $\begin{array}{c}\mathrm{U} j_{\mathrm{j}} \\
\text { munkaszervezés }\end{array}$ & $16,57 \%$ & $83,43 \%$ & $26,74 \%$ & $73,26 \%$ & 0,055 & nincs \\
\hline $\begin{array}{l}\text { Új technológia } \\
\text { bevezetése } \\
\text { vagy meglévő } \\
\text { korszerűsítése }\end{array}$ & $14,20 \%$ & $85,80 \%$ & $29,07 \%$ & $70,93 \%$ & 0,004 & van \\
\hline $\begin{array}{c}\text { Semmilyen } \\
\text { innováció nem } \\
\text { történt }\end{array}$ & \multicolumn{2}{|c|}{$57,40 \%$} & \multicolumn{2}{|c|}{$33,72 \%$} & $<0,001$ & van \\
\hline
\end{tabular}

Forrás: saját adatgyüités és számitás

Khi-négyzet próbával megvizsgáltuk azt is, hogy van-e összefüggés a válaszadók tervezési időhorizontja és a között, hogy mennyire könnyen tudnak banki és pályázati forrásokhoz jutni. A banki forrásokhoz való hozzáférhetőség esetében a mikrovállalkozások körében a khi-négyzet próba p-értéke 0,001 . Vagyis minél hosszabb időtávon tudnak a mikrovállalkozások tervezni a cégük üzleti életét illetően, annál jellemzőbb az, hogy a hatfokú Likert-skálán - melyben a hatos a legjobb értékelés - kedvezőbben értékelték a banki forrásokhoz való hozzáférhetőségüket. Ez fordítva is igaz, azaz minél inkább úgy érzik - vagy éppen tapasztalták -, hogy nem tudnak banki forráshoz jutni, annál rövidebb időtávon képesek tervezni. Ugyanez az összefüggés a mikrovállalkozások körében a pályázati források tekintetében már nem igazolható $(\mathrm{p}=0,055)$.

A kisvállalkozásokat tekintve mindkét típusú forrás és a tervezési időhorizont között statisztikailag igazolható összefüggés áll fenn. (A banki források esetében a p<0,001; míg a pályázati források esetében a $\mathrm{p}=0,031$.) 
Néhány sajátosságot ki kell emelnünk ebben az esetben is. A mikrovállalkozások közel 40\%-a legfeljebb 3-asra ${ }^{12}$ értékelte azt, hogy mennyire könnyen tud banki forrásokhoz jutni, míg kétharmad részük válaszolt ugyanígy a pályázati források esetében. A kisvállalkozások vezetői körében nem volt, aki azt válaszolta volna, hogy „egyáltalán nem tudok tervezni”. A mikrovállalkozások közel fele nem „lát” egy éven túlra, a kisvállalkozóknál ez az arány csupán $25 \%$ körüli. A tervezési horizont alakulását a két méretkategóriában kapott válaszok alapján szemléltetjük. Általános értelemben kijelenthető az is, hogy (főképpen) az elhúzódó válság, vagy krízishelyzetek katalizátorként hatnak a rövid távú tervezés folyamatára, valamint nagy hangsúlyt kapnak a különböző operatív tervezési, elemzési folyamatok, a negatív hatásoknak köszönhetően elkerülhetetlen módon előtérbe kerül az ún. válságmenedzsment szerepe. Ugyanakkor meg kell jegyezni azt is, hogy vannak olyan szegmentumok, ahol a válság pozitív előjellel hat a core business tevékenységekre, de ebben az esetben csak az előjel változik, az operatív tervezési időszak fajsúlya így is megnövekszik.

2. ábra: Milyen idôtávon tud tervezni vállalkozásában?

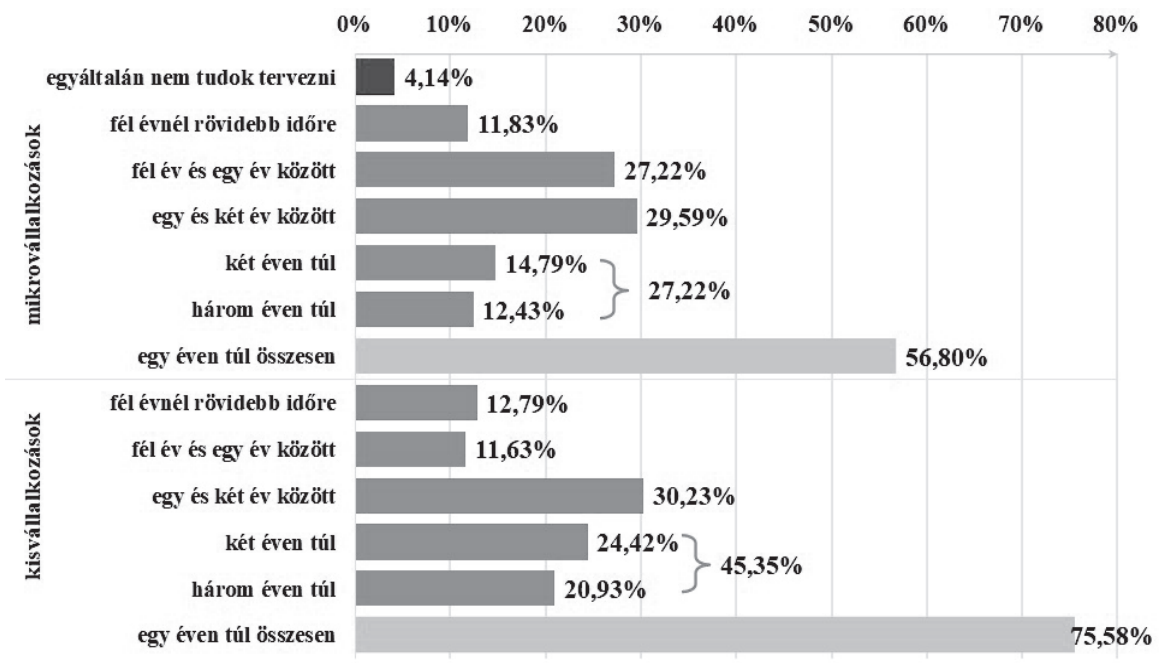

Forrás: saját adatgyüités és számítás

ForRÁSOK RENDELKEZÉSRE ÁLLÁSA

A banki és pályázati forrásokhoz való hozzáférést a kérdőives felmérés idején megvalósítás alatt álló beruházásokkal összefüggésben is vizsgáltuk. A khi-négyzet próbával végzett vizsgálatok eredménye alapján a banki forrásokhoz való hozzájutás és a folyamatban lévő beruházások esetében mindkét méretkategóriában szoros kapcsolatot tudtunk igazolni, a pályázati forrásokat tekintve viszont a „p” értéke mind a mikrovállalkozások, mind a kisvállalkozások esetében meghaladta a 0,05-ot. Ennek az lehet az oka, hogy a kisvállalkozások egyötöd részének, a mikrovállalkozások pedig alig egytizedének volt folyamatban valamilyen beruházása. 
Bujáki János - Pataki fános István: A mikro-és kisvállalkozások innovációs gyakorlatának...

A pályázati forrásokhoz való hozzájutásukat pedig mindkét méretkategória egyaránt 50-50\% körüli arányban minősítette a hatfokú Likert-skálán legfeljebb hármassal vagy legalább négyessel.

4. táblázat: A forrásokhoz való hozzáférés és a folyamatban lévó beruházások kapcsolata

\begin{tabular}{c|c|c}
\hline \multirow{2}{*}{ Megnevezés } & \multicolumn{2}{|c}{$\begin{array}{c}\text { Mennyire könnyen tud hozzájutni az adott típusú } \\
\text { forráshoz? }\end{array}$} \\
\cline { 2 - 3 } & Banki forrás & Pályázati forrás \\
\cline { 2 - 3 } & \multicolumn{2}{|c|}{ khi-négyzet próba ,p”-értéke } \\
\hline Mikrovállalkozások & 0,001 & 0,202 \\
\hline Kisvállalkozások & 0,024 & 0,119 \\
\hline
\end{tabular}

Forrás: saját adatgyüjtés és számitás

A vállalkozókat arról is megkérdeztük, hogy a felmérést követő legfeljebb öt évben tervezték-e valamilyen beruházás elindítását. Az elvégzett khi-négyzet próba alapján a két méretkategória között jelentős különbség áll fenn $(\mathrm{p}=0,005)$. Az adjusztált standardizált reziduum értéke az „igen, 3 éven belül” (2,6) és a „nem” $(3,5)$ válaszok esetében a 2,0-t is meghaladta, azaz a különbség ezen arányok között mutatkozott a legjelentősebbnek. A kisvállalkozások közel 60\%-a még öt éven belül sem tervez beruházást, a mikrovállalkozásoknál ez az arány még magasabb: közel 80\%-os. A kisvállalkozások a mikrovállalkozásokhoz képest minden időhorizonton legalább másfélszer-kétszer magasabb arányban terveztek valamilyen beruházást (Gamma együttható: 0,431; p=0,001).

3. ábra: Tervez-e jelenleg valamilyen beruházást vállalkozásában?

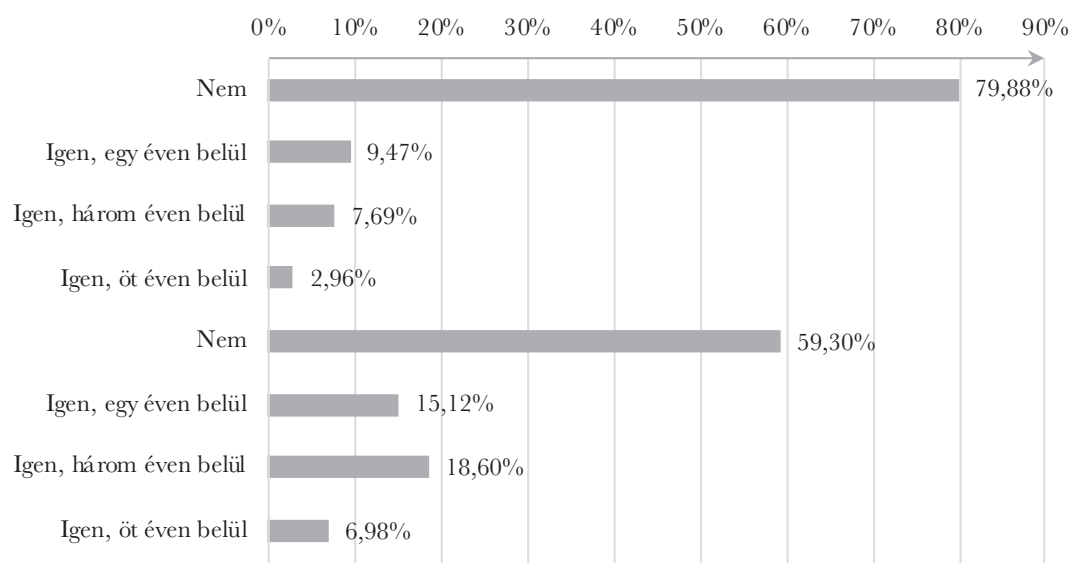

Forrás: saját adatgyüjtés és számítás 
A jelenleg folyamatban lévő beruházásokhoz hasonlóan khi-négyzet próbával vizsgáltuk azt is, hogy van-e statisztikailag igazolható kapcsolat a banki és pályázati forrásokhoz való hozzáférés és a tervezett, de még el nem indított beruházások között. A mikrovállalkozások körében a banki forrással kapcsolatban ez nem volt igazolható ( $\mathrm{p}=0,747)$, a kisvállalkozásokat vizsgálva viszont már szoros kapcsolatot mutat az eredmény $(\mathrm{p}=0,037)$. A pályázati források esetében szintén nem igazolható ilyen irányú összefüggés (mikrovállalkozások: $p=0,428$; kisvállalkozások: $\mathrm{p}=0,256)$.

Az egészségügyi veszélyhelyzet okán kialakult krízishelyzetben a már hivatkozott kormányzati válságkezelési stratégia a kisvállalkozások esetében több, a források bevonását elősegítő programot vezetett be a fenntarthatóság érdekében ${ }^{13}$, átfogó jellegét tekintve hasonlóan a 2013. évben a hitelbeszűkülés elkerülése okán bevezetésre kerül Növekedési Hitelprogram intézkedéseihez (Matolcsy, 2020b; Lentner, 2019:187-190). Ezen programok a vonatkozó jogszabályok manifesztációján keresztül kiválóan érzékeltetik a gazdaságpolitika alakítását. A kialakult válság teljes időszakában folyamatosan és rugalmasan reagálva a kormányzat - az Európai Unió szabályrendszerének ${ }^{14}$ mindenkori szem előtt tartása mellett -, többek között az alábbi rendelkezéseket hozta:

Megszületett a 1194/2020. (IV. 30.) Korm. határozat, amely a kisvállalkozások számára előnyösebb forrásbevonási lehetőséget biztosít, különféle programok bevezetésével a Széchenyi Kártya Program hitelkonstrukciók átdolgozásával, illetve fejlesztése mellett ${ }^{15}$, a koronavírus világjárvány mikro-, kis- és középvállalkozásokra gyakorolt gazdasági hatásainak mérséklése érdekében. A kormányzat azonnali hatállyal különféle pénzeszközöket csoportosított át, illetve biztosított a programok bevezetéséhez és realizációjához ${ }^{16}$. Hatályba lépett továbbá a 639/2020. (XII. 22.) Korm. rendelet, amely különféle adómegfizetési könnyebbségekről rendelkezett a kisvállalkozások számára ${ }^{17}$, valamint ezzel összhangban egy időben megszületett a 640/2020. (XII. 22.) Korm. rendelet, amely uniós jogi állami támogatási szabályokkal való összeegyeztethetőségről rendelkezett az Európai Unió ajánlásának ${ }^{18}$ megfelelő módon.

A 2021. évbe lépve a kormányzat alkalmazkodva a krízishelyzet (elhúzódó) körülményeihez hatályba léptette a 1271/2021. (V. 17.) Korm. határozatot, amely a kisvállalkozások érdekében kidolgozott programok szerinti egyes adókedvezményeknek a települési önkormányzatok felé jelentkező negatív hatásit ellensúlyozta ${ }^{19}$, ekként biztosítva az egyensúlyt és növelve a rendszer komplexitását.

A kormányzat a további segítségnyújtás okán hatályba léptette továbbá a 1368/2021. (VI. 10.) Korm. határozatot, amely elérhetővé tette a Széchenyi Kártya Újraindítási Folyószámlahitelt, a Széchenyi Újraindítási Likviditási Hitelt, és a Széchenyi Újraindítási Beruházási Hitel és ennek részét képező Agrár Széchenyi Újraindítási Beruházási Hitel konstrukciókat, valamint új konstrukcióként 2021. szeptember 01-jétől bevezette a Széchenyi Újraindítási Önerő Kiegészítő Hitelt és Széchenyi Újraindítási Lízingkonstrukciót.

\section{A FELMÉrés VIZSGÁlt TERÜLETEINEK ÖSSZEFüGGÉSEI}

Megvizsgáltuk, hogy a felmérés egyes vizsgált területeire vonatkozó kérdésekre kapott eredmények összefüggenek-e egy-egy területen belül, tehát összevonhatóak-e vizsgált terü- 
Bujáki János - Pataki fános István: A mikro-és kisvállalkozások innovációs gyakorlatának...

letenként egyetlen főkomponensbe, vagy esetleg vannak olyan kérdések, amelyek esetében nem igazolható összefüggés az adott területet vizsgáló más kérdések eredményeivel. A főkomponenseket Mann-Whitney próbával vizsgáltuk abból a célból, hogy ellenőrizzük, az egyes területeken belül igazolható-e a mikro- és kisvállalkozások között jelentős különbség (a Mann-Whitney nemparaméteres próba választásának oka, hogy a két vizsgált csoportban a Kolmogorov-Smirnov próba nem igazolt normális eloszlást a főkomponens-koordináták között). A vizsgálatba a következő három területet vontuk be: tervezési gyakorlat és lehetőségek, forrásokhoz való hozzáférés és kérdőíves felmérést megelőző öt év innovációs teljesítménye.

A két méretkategória tervezési gyakorlatát és lehetőségeit elemezve egy főkomponens alakult ki, melyet Mann-Whitney próbával $(\mathrm{p}<0,001)$ vizsgálva jelentős különbség igazolható a mikro- és kisvállalkozások között. Az átlagos rangszám értékek szerint a mikrovállalkozások tervezési lehetőségei jelentősen elmaradnak a kisvállalkozásokéitól. A külső forrásokhoz való hozzáférésre vonatkozó kérdések szintén összevonhatók voltak egyetlen főkomponensbe, a Mann-Whitney próba p-értéke $(p<0,001)$ alapján ez esetben is jelentősnek bizonyult a különbség a méretkategóriák között - az átlagos rangszám értékek alapján megállapítható, hogy a nagyobb vállalati méret könnyebb forráshoz jutási lehetőségekkel jár. A vállalkozások elmúlt öt éves innovációs teljesítményét vizsgálva kettő főkomponens született. A rotált főkomponens mátrixban az első főkomponens tartalmazta az új termék, szolgáltatás, technológia és munkaszervezés bevezetését, míg a második főkomponensbe az ERP- és a CRM-rendszer bevezetése került. A Mann-Whitney próba p-értéke csak az első főkomponens esetében igazolt jelentős különbséget a méretkategóriák között (1.: p=0,001; 2.: p=0,290), a mikrovállalkozások átlagos rangszám értéke viszont mindkét esetben elmarad a kisvállalkozásokéitól.

5. táblázat: Összefoglaló táblázat

\begin{tabular}{|c|c|c|c|c|c|}
\hline \multirow{2}{*}{ Megnevezés } & \multicolumn{3}{|c|}{ Átlagos rangszám értéke } & \multicolumn{2}{|c|}{$\begin{array}{c}\text { Mann-Whitney próba } \\
\text { eredménye }\end{array}$} \\
\hline & $\begin{array}{l}\text { Mikrovállal- } \\
\text { kozások }\end{array}$ & Reláció & $\begin{array}{l}\text { Kisvállal- } \\
\text { kozások }\end{array}$ & p-érték & $\begin{array}{c}\text { szignifikáns } \\
\text { különbség }\end{array}$ \\
\hline $\begin{array}{c}\text { Tervezési gyakorlat és } \\
\text { lehetőségek }\end{array}$ & 113,81 & $<$ & 155,89 & $<0,001$ & van \\
\hline $\begin{array}{l}\text { Forrásokhoz való } \\
\text { hozzáférés }\end{array}$ & 113,67 & $<$ & 156,15 & $<0,001$ & van \\
\hline \multicolumn{6}{|l|}{$\begin{array}{l}\text { A felmérést megelőző öt év } \\
\text { innovációs teljesítménye }\end{array}$} \\
\hline $\begin{array}{l}\text { 1. fökomponens (új termék, } \\
\text { szolgáltatás, technológia és } \\
\text { munkaszervezés bevezetése) }\end{array}$ & 117,81 & $<$ & 148,02 & 0,001 & van \\
\hline $\begin{array}{l}\text { 2. fókomponens (ERP- és } \\
\text { CRM-rendszer bevezetése) }\end{array}$ & 124,74 & $<$ & 134,40 & 0,290 & nincs \\
\hline
\end{tabular}

Forrás: saját adatgyüjtés és számitás 
A felmérést megelőző öt év innovációs teljesítményében tetten érhető különbségeket a 4. ábrán is szemléltetjük. A sugárdiagramon a Mann-Whitney próba Z- és p-értékeit jelenítettük meg piros felirattal kiemelve azokat az ismérvváltozatokat, ahol a módszer jelentős különbséget igazolt.

\section{4. ábra: A felmérést megelözó öt év innovációs teljesitménye}

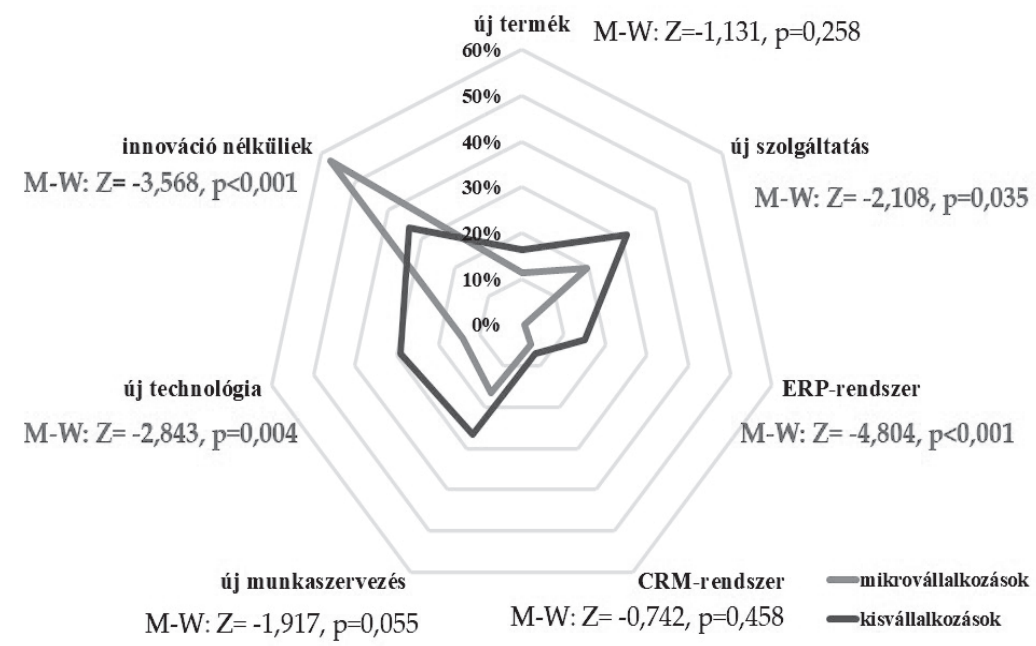

Forrás: saját adatgyujités és számítás

\section{ÖSSZEFOGLALÁS}

Mind a hazai, mind a nemzetközi szakirodalom alig-alig foglalkozik kimondottan a két legkisebb vállalati méretkategória specifikus vizsgálatával. Nem meglepő tehát, hogy a mikroés kisvállalkozások a nemzetgazdaságban betöltött súlyukhoz képest a korábbi évtizedekben méltatlanul kevés figyelemben részesültek. Ez a trend azonban az elmúlt néhány év során változni látszik, ugyanis a kormányzat jól láthatóan felismerte a kisvállalkozások és a családi cégek szerepét, és figyelemmel a COVID-19 egészségügyi veszélyhelyzetre - mint egyféle katalizátor által is generált gazdasági válsághelyzetre - vonatkozóan, kiemelten ezen vállalkozások támogatása céljából hívta életre többek között az ismertetett operatív programokat. A két méretkategória között több területet elemezve levonjuk a következtetést: a magasabb létszámmal működő kisvállalkozások kedvezőbben ítélték meg saját környezetüket és lehetőségeiket, beruházási és innovációs hajlandóságuk pedig jelentősen felülmúlta a mikrovállalkozásokét. Meggyőződésünk, hogy a mikro- és kisvállalkozások üzleti környezetének javítása, forrásfelvételi lehetőségeinek és innovációs teljesítményének fejlesztése a mindenkori kormány feladatai között a legmagasabb prioritással kell szerepeljen. Hangsúlyozzuk azonban, hogy a fiskális és monetáris politika támogató hozzáállása szükséges, de nem elégséges - a hosszú távon is sikeres versenyképességhez elengedhetetlen a vállalkozók tudatos stratégiai tervezése. 


\section{JEGYZETEK}

1 Kkv. tv. 3. § (1) KKV-nak minősül az a vállalkozás, amelynek

a) összes foglalkoztatotti létszáma 250 főnél kevesebb, és

b) éves nettó árbevétele legfeljebb 50 millió eurónak megfelelő forintösszeg, vagy mérlegfőösszege legfeljebb 43 millió eurónak megfelelő forintösszeg.

(2) A KKV kategórián belül kisvállalkozásnak minősül az a vállalkozás, amelynek

a) összes foglalkoztatotti létszáma 50 főnél kevesebb, és

b) éves nettó árbevétele vagy mérlegföösszege legfeljebb 10 millió eurónak megfelelő forintösszeg.

(3) A KKV kategórián belül mikrovállalkozásnak minősül az a vállalkozás, amelynek

a) összes foglalkoztatotti létszáma 10 főnél kevesebb, és

b) éves nettó árbevétele vagy mérlegföösszege legfeljebb 2 millió eurónak megfelelő forintösszeg.

Kkv. tv. 3. $\S(6)$.

3 Kkv. tv. 3. § (4) Nem minősül KKV-nak az a vállalkozás, amelyben az állam vagy az önkormányzat közvetlen vagy közvetett tulajdoni részesedése - tőke vagy szavazati joga alapján - külön-külön vagy együttesen eléri, vagy meghaladja a $25 \%$-ot.

4 Kkv. tv. 3. § (5) A (4) bekezdésben foglalt korlátozó rendelkezést nem kell alkalmazni, ha a 19. § 1. pontjában meghatározott befektetők állnak a vállalkozással a 4. § (2) bekezdése szerinti kapcsolatban. Vö. EBH2014. K.18.

5 A továbbiakban megkülönböztetés nélkül: kisvállalkozások.

6 Vö. Robinson és Pearce, 1984., pp. 128-129.

Vö. Robinson és Pearce, 1984., pp. 133-136.

8 Kkv. tv. 10. § A KKV-kkal kapcsolatos állami feladatokat a gazdaságfejlesztésért felelős miniszter hangolja össze. Ennek körében

a) értékeli a KKV-k állami támogatásának hatékonyságát, valamint kidolgozza az értékelés módszertanát,

b) kidolgozza és jóváhagyásra a Kormány elé terjeszti a KKV-k fejlesztésének stratégiáját, a KKV-fejlesztési politika fő célkitűzéseit és javaslatokat tesz a KKV-k fejlesztését szolgáló intézkedésekre,

c) az egységes európai piac folyamataiba való bekapcsolódás, illetve részvétel érdekében gondoskodik a KKV-k felkészítésével, és fejlesztésével kapcsolatos állami feladatok végrehajtásáról,

d) elősegíti a KKV-k számára hasznosítható ismeretek és tudás, a hazai és külföldi kutatási és fejlesztési eredmények megismerését, elterjesztését, illetve a KKV-k innovációs képességének javítását.

11. § A gazdasági szabályozó rendszer egyes elemeinek módosítása során, valamint a KKV-kat is érintő jogszabály-módosítások előterjesztésében be kell mutatni a tervezett változtatásoknak a KKV-k gazdasági helyzetére gyakorolt hatását.

9 Kkv. tv. 15. § A Vállalkozásfejlesztési Tanács részt vesz a KKV-fejlesztési stratégia kialakításában, ennek keretében:

a) javaslatot tesz a KKV-fejlesztési stratégia megalapozását szolgáló szakmai programokra és intézkedésekre,

b) véleményezi a KKV-k fejlesztése céljából kialakított szakmai programokat,

c) javaslatot tesz a célelőirányzatból támogatandó célokra és a források célok közötti felosztási arányaira, különös tekintettel arra, hogy a mikro- és kisvállalkozások is megfelelő mértékben részesüljenek a támogatásokból,

d) értékeli a központi államigazgatási szervek és KKV-fejlesztési szervezetek költségvetési forrás felhasználásával működtetett programjainak hatékonyságát, valamint összhangját a KKV-fejlesztési stratégiával,

e) értékeli a KKV-k részesedésének mértékét a költségvetési támogatásokból, a vállalkozói hitelekből, valamint a közbeszerzésekből,

f) véleményezi a KKV-kat érintő törvénytervezeteket,

g) javaslatot fogalmaz meg a KKV-kat érintő szabályozási környezet kialakítására,

h) javaslatot tesz a KKV-k helyzetét érintő hatástanulmányok elkészítésére.

10 Az Európai Parlament és a Tanács (EU) 2021/690 Rendelete (2) A belső piacnak folyamatosan alkalmazkodnia kell a digitális forradalom és a globalizáció által jellemzett, gyorsan változó környezethez. A digitális innováció új korszaka továbbra is lehetőségeket teremt a vállalkozások és a magánszemélyek számára, új termékeket, szolgál- 


\section{Polgári Szemle $\cdot 17$ évfolyam 4-6. szám}

tatásokat, folyamatokat és üzleti modelleket hoz létre, valamint új lehetőségeket kínál a magas színvonalú statisztikák hatékony előállításához. Ugyanakkor kihívások is fakadnak belőle a szabályozás, a szabályok érvényesítése, a fogyasztóvédelem és biztonság tekintetében.

11 GINOP-8.3.5-18 mikro-, kis- és középvállalkozások technológiai korszerűsítése célú hitelprogram „A Hitelprogram célja a mikro-, kis-és középvállalkozások technológiai korszerűsítése, illetve a korszerű termék-és szolgáltatásfejlesztési képességének megteremtése, bővitésének támogatása, amelynek egyedi célkitűzése a finanszírozási forrásokhoz nem, vagy nem megfelelő mértékében hozzájutó mikro-, kis-és középvállalkozások fejlesztése a mikro-, kis-és középvállalkozások külső finanszírozáshoz történő hozzáférésének javítása révén. A támogatott beruházásnak olyan fejlesztést kell eredményeznie, ami javítja a technológiai felkészültséget. A Hitelprogram célja a mikro-, kis-és középvállalkozások olyan beruházásainak a támogatása, amelyek pénzügyi szempontból életképesek, jövedelemtermelők."

12 A hatfokú Likert-skálán 1-es volt a legkevésbé kedvező, a 6-os a leginkább kedvező érték.

13 Matolcsy, 2020b, ,2020 elején beütött Európa harmadik válsága. A Covid-19 járvány nyomában az EU-országok többségében gazdasági válság alakul ki. Már látszik, hogy akik jól kezelték a járványt, azoknál jobbak az idei gazdasági kilátások, és ez megfordítva is igaz. Azoknál még jobbak a várható gazdasági adatok, akik nem élték át az eurózóna hosszú, 2008/2009 és 2019 közötti először nyílt, majd lappangó válságát. Még ennél is jobb az idei várható gazdasági eredmény ott, ahol képesek az önálló nemzeti pénzpolitika eszközeit célzottan használni.” https://www.mnb.hu/sajtoszoba/elnoki-publikaciok/2020-evi-publikaciok/europa-harom-valsaga (2021. 06. 30.)

14 Kkv tv. 20. § (7) Ez a törvény a mikro-, kis- és középvállalkozások meghatározásáról szóló 2003. május 6-i 2003/361/EK bizottsági ajánlásnak való megfelelést szolgálja.

(8) A 7. § (2) bekezdés u) pontja az energiahatékonyságról, a 2009/125/EK és a 2010/30/EU irányelv módosításáról, valamint a 2004/8/EK és a 2006/32/EK irányelv hatályon kívül helyezéséről szóló, 2012. október 25-i 2012/27/EU európai parlamenti és tanácsi irányelv 8. cikk (2) bekezdésének való megfelelést szolgálja.

15 1194/2020. (IV. 30.) Korm. határozat 1. A Kormány 1.1. a koronavírus világjárvány negatív gazdasági hatásainak mérséklése érdekében a hazai mikro-, kis- és középvállalkozások likviditási nehézségeinek enyhítése, valamint beruházásaik megvalósítása érdekében 2020. május 15. napjától a Széchenyi Kártya Program Keretében

a) Széchenyi Kártya Folyószámlahitel Plusz,

b) Széchenyi Munkahelymegtartó Hitel,

c) Széchenyi Likviditási Hitel,

d) Széchenyi Beruházási Hitel Plusz programokat indít.

16 1194/2020. (IV. 30.) Korm. határozat 3.2. felhívja a pénzügyminisztert, hogy gondoskodjon 2900000000 forint összegü többletforrás biztosításáról a gazdaságfejlesztést szolgáló feladatok finanszírozása céljából a Magyarország 2020. évi központi költségvetéséről szóló 2019. évi LXXI. törvény (a továbbiakban: Kvtv.) 1. melléklet XVII. Innovációs és Technológiai Minisztérium fejezet, 20. Fejezeti kezelésű előirányzatok cím, 33. Hazai fejlesztési programok alcím, 3. Gazdaságfejlesztést szolgáló célelőirányzat jogcímcsoport javára;

Felelős: pénzügyminiszter

Határidő: azonnal

3.3. Felhívja a pénzügyminisztert, hogy az innovációért és technológiáért felelős miniszter bevonásával gondoskodjon a gazdaságfejlesztést szolgáló feladatok finanszírozásához szükséges összeg, de legfeljebb 18100000000 forint biztosításáról 2021. évben a XVII. Innovációs és Technológiai Minisztérium fejezet Gazdaságfejlesztést szolgáló célelőirányzat javára.

17 639/2020. (XII. 22.) Korm. rendelet 2. § (1) A (3) bekezdésben meghatározott adatok alapján a mikro-, kis- és középvállalkozásnak minősülő vállalkozónak a 2021. évben, az adott előleg-fizetési időpontban esedékes - a Htv. szerint bevallott és a 2021. évben az önkormányzati adórendelet szerinti adómértékkel bevallandó - adóelőleg 50 százalékát kell az egyes esedékességi időpontokban megfizetni.

18 (EU) 2021/801 Ajánlása Az Európai Bizottság, tekintettel az Európai Unió működéséről szóló szerződésre és különösen annak 292. cikkére, mivel:

(1) A Covid19-járvány kitörése nyomán példátlan nemzeti és uniós szintủ fellépésekre került sor az EU gazdaságának támogatása és a talpraállás elősegítése érdekében. A rövid távú válságkezelési intézkedések többsége azt kívánja biztosítani, hogy a vállalkozások megfelelő pénzforgalommal rendelkezzenek. 
(2) A népegészségügyi intézkedések különösen a kis- és középvállalkozásokat (kkv-k) érintik súlyosan, mivel gyakran kevésbé képesek a veszteségeket elviselni vagy finanszírozni, mint a nagyobb vállalatok. A kkv-k emellett nagyobb valószínűséggel tevékenykednek olyan üzleti ágazatokban, amelyeknek be kellett zárniuk a népegészségügyi intézkedések miatt (például szállodák, éttermek, kávéházak és bárok).

(3) Számos joghatóság gyors lépéseket tett annak érdekében, hogy csökkentse a vállalkozások közvetlen adóterheit olyan, megfelelő támogatási intézkedésekkel, amelyek jelentős része az uniós állami támogatási szabályok, különösen az állami támogatási intézkedésekre vonatkozó új, ideiglenes keret hatálya alá tartozik.

19 1271/2021. (V. 17.) Korm. határozat A Kormány 1. a koronavírus-világjárvány nemzetgazdaságot érintő hatásának enyhítése érdekében a mikro-, kis- és középvállalkozásokat a helyi iparűzési adó rendszerén keresztül is támogatja, és ezzel együtt megvizsgálta a huszonötezer főnél nagyobb lakosságszámú települések önkormányzatai támogatásának lehetőségét, melynek alapján

a) az 1. mellékletben meghatározott települések önkormányzatai számára az ott meghatározott összegű támogatást,

b) a 2. mellékletben meghatározott települések önkormányzatai számára az ott meghatározott összegű fejlesztési támogatást biztosítja.

\section{FELHASZnÁlt IRODALOM}

Andrew, J. P. - Sirkin, H. L. (2003): Innovating for cash, In: Harvard Business Review, September 2003, https://hbr. org/2003/09/innovating-for-cash 1 (2021. 07. 01.)

Baltas, G. - Lioukas, S. - Salavou, H. (2004): Organisational innovation in SMEs: The importance of strategic orientation and competitive structure", In: European fournal of Marketing, Vol. 38 No. 9/10, p. 1091-1112.

Battisti, M. - Deakins, D. - Roxas, H., (2010): The case of Innovation and RED in Nerw Zealand's small and medium-sized enterprises: Too many small firms? New Zealand Centre for SME Research, Massey University, Wellington, Australia.

Csath Magdolna - Nagy Balázs - Taksás Balázs - Vinogradov Szergej - Györpál Tünde (2018): Jelentés az állam versenyképességet javitó, vállalkozóbarátabb üzleti környezet megteremtését célzó, szükséges és lehetséges feladatait vizsgáló kutatásról, Nemzeti Közszolgálati Egyetem, Budapest, 4. szám.

De Sousa, M. (2006): The sustainable innovation engine. In: The fournal of Information and Knowledge Management Systems, Vol. 34 No. 6, pp. 398-405.

Drucker, P. F. (2002): The discipline of innovation. In: Harvard Business Review, September 2002, pp. 5-11.

Ennis, S. (1998): Marketing planning in the smaller evolving firm, empirical evidence and reflections, Irish Marketing Review, 11(2), pp. 49-61.

Faherty, U. - Stephens, S. (2016): Innovation in micro enterprises: reality or fiction? In: Fournal of Small Business and Enterprise Development, Vol. 23, Iss. 2. pp. http://dx.doi.org/10.1108/JSBED-11-2013-0176 (2021. 07. 01.)

GINOP-8.3.5-18-Mikro-, kis-és középvállalkozások technológiai korszerüsitése célú hitelprogram.

Kormányhivatal (2021): Tájékoztató a kis, közép, és mikro vállalkozások besorolásáról https://www.kormanyhivatal.hu/ download/1/ab/f5000/T\%C3\%81J\%C3\%89KOZTAT\%C3\%93\%20-\%20KKV-k\%20besorol\%C3\%Alsa. pdf (2021.07.01.)

KSH (2019): A kis-és középvállalkozások jellemzőí, 2018, Központi Statisztikai Hivatal.

KSH (2021): A vállalkozások teljesítménymutatói kis-és középvállalkozási kategória szerint, https://www.ksh.hu/docs/hun/ xstadat/xstadat_eves/i_qta005.html (2021.07.01.)

Lentner Csaba (2019): A magyar állampénzügyek fejlódéstörténete a dualizmus korától napjainkig, L'Harmattan Kiadó.

Lyles, A. M. - Baird, I. S. - Orris, J. B. - Kuratko, D. F. (1993): Formalized planning in small business: Increasing strategic choices. In: Journal of Small Business Management, Vol. 31, pp. 38-50.

Matolcsy György (2020a): Egyensúly és növekedés 2010-2019 - Sereghajtóból újra éllovas, Magyar Nemzeti Bank.

Matolcsy György (2020b): Európa három válsága. Magyar Nemzeti Bank, https://www.mnb.hu/sajtoszoba/elnoki-publikaciok/2020-evi-publikaciok/europa-harom-valsaga (2021. 06. 30)

Mazzarol, T. - Clark, D. N. - Reboud, S. (2014): Strategy in action: Case studies of strategy, planning and innovation in Australian SMEs, Small Enterprise Research, 21:1, pp. 54-71, DOI: 10.1080/13215906.2014.11082076.

Miller, D. (1983): The correlates of entrepreneurship in three types of firms, In: Management Science, Vol. 29, pp. 


\section{Polgári Szemle · 17. évfolyam 4-6. szám}

770-791.

OECD (2010): SMEs: Entrepreneurship and Innovation, In: Paris France: Organisation for Economic Co-operation and Development.

Robinson, R.B. - Pearce, J.A. (1984): Research thrusts in small firm strategic planning, In: Academy of Management Review, 9, pp. 128-137.

Vonnák Balázs (2019): Mit tanulhat a közgazdaságtan a válságból? In: A jövő fenntartható Közgazdaságtana, Magyar Nemzeti bank, pp. 25-30.

Woods, A. - Joyce, P. (2003): Owner-managers and the practice of strategic management, In: International Small Business fournal, 21(2), pp. 181-195.

\section{FelhasZnÁlT JOGSZABÁLYOK}

2004. évi XXXIV. törvény - a kis- és középvállalkozásokról, fejlődésük támogatásáról.

EBH2014. K.18. - Egy vállalkozás csak akkor veszíti el a kis- és középvállalkozás minősítést, ha két egymást követő beszámolási időszakban túllépi a törvényben meghatározott határértékeket.

1194/2020. (IV. 30.) Korm. határozat - a Gazdaságvédelmi Akcióterv keretében a koronavírus világjárvány mikro-, kis- és középvállalkozásokra gyakorolt gazdasági hatásainak mérséklése érdekében létrehozandó Széchenyi Kártya Program hitelkonstrukciókról.

639/2020. (XII. 22.) Korm. rendelet - a koronavírus-világjárvány nemzetgazdaságot érintő hatásának enyhítése érdekében szükséges egyes intézkedésekről.

640/2020. (XII. 22.) Korm. rendelet - a koronavírus-világjárvány nemzetgazdaságot érintő hatásának enyhítése érdekében szükséges egyes intézkedésekről szóló 639/2020. (XII. 22.) Korm. rendelet szerinti intézkedés uniós jogi állami támogatási szabályokkal való összeegyeztethetőségéről.

129/2021. (III. 13.) Korm. rendeletet - a koronavírus-világjárvány nemzetgazdaságot érintő hatásának enyhítése érdekében szükséges egyes intézkedésekről szóló 639/2020. (XII. 22.) Korm. rendelet szerinti intézkedés uniós jogi állami támogatási szabályokkal való összeegyeztethetőségéről szóló 640/2020. (XII. 22.) Korm. rendelet módosításáról.

1271/2021. (V. 17.) Korm. határozat - a koronavírus-világjárvány nemzetgazdaságot érintő hatásának enyhítése kapcsán szükséges intézkedésekről.

1368/2021. (VI. 10.) Korm. határozat - a Gazdaság-újraindítási Akcióterv keretében a Széchenyi Kártya Újraindítási Program bevezetéséről.

Az Európai Parlament és a Tanács (EU) 2021/690 Rendelete - (2021. április 28.) a belső piacra, a vállalkozások - köztük a kis- és középvállalkozások - versenyképességére, a növények, állatok, élelmiszerek és takarmányok területére, valamint az európai statisztikákra vonatkozó program (Egységes piac program) létrehozásáról, továbbá a 99/2013/EU, az 1287/2013/EU, a 254/2014/EU és a 652/2014/EU rendelet hatályon kívül helyezéséről.

A Bizottság 2021. május 18-i (EU) 2021/801 Ajánlása - a Covid19-válság során elszenvedett veszteségek adóügyi megítéléséről. 